\title{
AKTIVITAS ANTI MAKAN EKSTRAK DAUN SIRSAK (ANNONA MURICATA L.) DAN PENGARUHNYA TERHADAP INDEKS NUTRISI SERTA TERHADAP STRUKTUR MEMBRAN PERITROFIK LARVA INSTAR V SPODOPTERA LITURA F.
}

\author{
Trisnowati B. Ambarningrum ${ }^{1}$, Endang A. Setyowati ${ }^{1} \&$ Priyo Susatyo ${ }^{2}$ \\ ${ }^{1}$ Lab. Entomologi-Parasitologi, Fakultas Biologi, Universitas Jenderal Soedirman, Purwokerto \\ E-mail : trisnowatibudi@yahoo.com \\ ${ }^{2}$ Lab. Struktur dan Perkembangan Hewan, Fakultas Biologi, Universitas Jenderal Soedirman, Purwokerto
}

\begin{abstract}
Antifeeding activity of soursop leaf extract (Annona muricata L.) and its effect on nutrition indices and the peritrophic membrane structure of the fifth-instar larvae of Spodoptera litura $\boldsymbol{F}$. Antifeeding activity of soursop leaf extract (Annona muricata $\mathrm{L}$.) and its effect on nutrition indices and the microscopic structure of peritrophic membrane of the fifth-instar larvae of Spodoptera litura F. were studied. Antifeeding test was conducted by choice method. Discs of caisin leaf were dipped into the ether fraction of soursop leaf extract with concentrations of $0 ; 0.63 ; 2.50$; and $10.00 \%$. Nutrition indices and peritrophic membrane structure were observed by giving fifth-instar larvae one of the five diets, every group of diet was added to various concentrations of the ether fraction of soursop leaf extract, containing either $0 ; 0.63 ; 1.25 ; 2.50$; and $5.00 \%$. The result showed that soursop leaf extract had antifeeding activity at tested concentration $2.50 \%$. Relative consumption rate (RCR), relative growth rate (RGR), and efficiency of conversion of ingested food (ECI) were significantly lower in the case of treated larvae than that of the controls. However the efficiency of conversion of digested food (ECD), approximate digestibility (AD), and peritrophic membrane structure treated with soursop leaf extract were not significantly affected as compared to those in controls.
\end{abstract}

Key words : Spodoptera litura, soursop leaf extract, antifeeding activity, nutrition indices, membrane peritrophic structure

\section{ABSTRAK}

\begin{abstract}
Aktivitas anti makan ekstrak daun sirsak (Annona muricata L.) dan pengaruhnya terhadap indeks nutrisi serta struktur membran peritrofik larva instar $V$ Spodoptera litura $\boldsymbol{F}$. Telah dilakukan penelitian untuk menguji aktivitas anti makan ekstrak daun sirsak (Annona muricata $\mathrm{L}$.) dan pengaruhnya terhadap indeks nutrisi serta struktur membran peritrofik larva instar $\mathrm{V}$ Spodoptera litura F. Uji anti makan menggunakan metode memilih. Daun caisin berbentuk lingkaran dicelupkan ke dalam ekstrak daun sirsak fraksi eter dengan konsentrasi $0 ; 0,63 ; 2,50$; dan 10,00\%. Indeks nutrisi dan pengamatan struktur membran peritrofik dilakukan dengan metode pemberian pakan. Masing-masing pakan mengandung ekstrak daun sirsak fraksi eter dengan konsentrasi $0 ; 0,63 ; 1,25 ; 2,50 ;$ dan 5,00\%. Hasil penelitian menunjukkan bahwa ekstrak daun sirsak memiliki aktivitas sebagai anti makan mulai konsentrasi 2,50\%. Perlakuan dengan konsentrasi 0,$63 ; 1,25 ; 2,50 ;$ dan 5,00\% menurunkan laju konsumsi relatif (RCR), laju pertumbuhan relatif (RGR), dan efisiensi konversi pakan yang dimakan (ECI), namun tidak mempengaruhi efisiensi konversi pakan yang dicerna (ECD) dan perkiraan pakan yang dicerna (AD) dari larva uji serta tidak mempengaruhi struktur membran peritrofik larva uji.
\end{abstract}

Kata kunci : Spodoptera litura, ekstrak daun sirsak, aktivitas anti makan, indeks nutrisi, dan struktur membran peritrofik

\section{PENDAHULUAN}

Larva Spodoptera litura (Lepidoptera : Noctuidae) merupakan serangga polifagus yang menyerang banyak jenis tanaman pertanian. Stadium larvanya dilaporkan menyerang daun tanaman kedelai, kacang tanah, tomat, cabe, kentang, kubis, sawi, dan tembakau (Kalshoven, 1981). Serangan larva serangga ini menurunkan kualitas hasil panen dan kehilangan hasil yang tidak sedikit. Marwoto \& Suharsono (2008) mengatakan bahwa kehilangan hasil akibat serangan $S$. litura pada tanaman kedelai dapat mencapai $80 \%$, dan serangan berat menyebabkan puso (gagal panen).

Hingga kini pengendalian larva S. litura ditingkat petani umumnya masih mengandalkan insektisida sintetis, namun kurang efektif. Berkembangnya resistensi hama 
terhadap insektisida sintetis dan meningkatnya kesadaran masyarakat akan dampak buruk penggunaan insektisida sintetis secara intensif telah mendorong timbulnya pemikiran untuk mengembangkan teknik pengendalian hama yang ramah lingkungan. Salah satu alternatifnya adalah dengan memanfaatkan tumbuhan sebagai insektisida botani.

Salah satu tumbuhan yang dilaporkan memiliki aktivitas insektisida adalah tumbuhan sirsak (Annona muricata). Daun sirsak mempunyai prospek untuk dikembangkan sebagai insektisida botani. Daun sirsak mengandung senyawa acetogenin antara lain asimisin, bulatasin, dan squamosin (Kardinan, 2005). Senyawa anonain yang terkandung dalam ekstrak Annona sp bersifat sebagai penolak serangga (Prijono, 1999). Menurut Tjokronegoro (1987) ekstrak daun sirsak menyebabkan kematian larva Bombyx mori pada konsentrasi 3,5 mg dalam $1 \mathrm{~g}$ pakan buatan serta bersifat anti makan terhadap Crocidolomia binotalis. Simanjuntak et al. (2007) mengatakan bahwa serbuk daun sirsak dapat digunakan untuk mengendalikan rayap dan dosis $6 \mathrm{~g} /$ toples telah menyebabkan mortalitas pada rayap uji, selanjutnya Yus (1996) melaporkan bahwa $\mathrm{LC}_{50}$ ekstrak biji sirsak terhadap larva instar V Heliothis armigera adalah sebesar 3,437\%. Komansilan et al (2012) mengatakan bahwa ekstrak biji sirsak fraksi nheksan dengan nilai $\mathrm{LC}_{50-}$ sebesar $73,77 \mathrm{ppm}$ efektif menekan populasi larva Aedes aegypti pada skala laboratorium. Menurut Dadang et al (2009) efikasi insektisida botani yang dicampur, yaitu berupa ekstrak Piper retrofractum yang dicampur dengan ekstrak $A$. squamosa dan ekstrak Aglaia odorata yang dicampur dengan A. squamosa pada konsentrasi $0,1 \%$ efektif menekan populasi larva Crocidolomia pavonna dan Plutella xylostella serta tidak mempengaruhi keberadaan parasitoid Diadegma semiclausum dan Eriborus argentiopilosus.

Pengujian beberapa bagian tanaman sirsak terhadap berbagai serangga hama sudah pernah dilakukan oleh beberapa peneliti, namun biasanya hanya diarahkan dengan maksud untuk mendapatkan konsentrasi efektif yang dapat menyebabkan mortalitas tinggi dari serangga uji, sedangkan bagaimana cara kerja dan efek fisiologisnya terhadap serangga uji belum banyak dilakukan. Cara kerja dari suatu senyawa alelokimia penting untuk diketahui karena sifat serangga yang berbeda-beda, sehingga senyawa akan bekerja selektif.

Penelitian ini bertujuan untuk mengetahui pengaruh aktivitas anti makan dari ekstrak daun sirsak fraksi eter terhadap larva $S$. litura instar V, untuk mengetahui pengaruh ekstrak daun sirsak fraksi eter terhadap indeks nutrisi larva $S$. litura instar V yang meliputi laju konsumsi relatif (RCR), laju pertumbuhan relatif (RGR), efisiensi konversi pakan yang dimakan (ECI), efisiensi konversi pakan yang dicerna (ECD) dan perkiraan pakan yang dicerna (AD), serta untuk mengetahui pengaruh ekstrak daun sirsak fraksi eter terhadap struktur membran peritrofik larva S. litura instar V.

\section{METODE PENELITIAN}

Tempat dan Waktu Penelitian. Penelitian dilakukan di Laboratorium Entomologi-Parasitologi serta Laboratorium Struktur dan Perkembangan Hewan, Fakultas Biologi, Universitas Jenderal Soedirman, Purwokerto pada bulan Januari sampai Oktober 2010.

Bahan utama yang digunakan dalam penelitian ini meliputi ekstrak daun sirsak fraksi eter, larva S. litura, daun caisin, dan pakan buatan (Singh \& Moore, 1985 dalam Lestari, 2009). Dalam penelitian ini terdapat tiga varibel yang diamati yaitu 1). pengaruh ekstrak daun sirsak terhadap anti makan $S$. litura, 2). pengaruh ekstrak daun sirsak terhadap indeks nutrisi, dan 3). pengaruh ekstrak daun sirsak terhadap struktur membran S. litura.

Uji Anti Makan. Uji anti makan dilakukan untuk melihat kemungkinan adanya senyawa dalam ekstrak yang bersifat sebagai anti makan. Uji anti makan dilakukan dengan metode memilih (choice method) menggunakan daun caisin berbentuk lingkaran dengan diameter $5 \mathrm{~cm}$. perlakuan disusun dengan Rancangan Acak Lengkap dengan empat perlakuan konsentrasi ekstrak daun sirsak. Konsentrasi yang digunakan adalah $0,0 \%$ $0,63 \% ; 2,50 \%$; dan $10,00 \%$. Perlakuan menggunakan lima ekor larva yang ditempatkan dalam toples secara individual. Masing-masing perlakuan diulang tiga kali.

Perlakuan dilakukan dengan cara mencelupkan satu lembar daun caisin ke dalam larutan uji sebagai perlakuan dan satu lembar daun yang lain dicelupkan ke dalam larutan kontrol. Setelah dicelupkan daun dikering anginkan sebentar, untuk selanjutnya ditempatkan dalam toples berdiameter $15 \mathrm{~cm}$. Masingmasing toples berisi satu daun kontrol dan satu daun perlakuan, dan ditengahnya dilepaskan satu ekor larva S. litura instar V yang sebelumnya telah dipuasakan terlebih dahulu.

Evaluasi dilakukan setelah empat jam perlakuan. Luas daun yang dimakan pada masing-masing perlakuan dibandingkan dengan kontrol dengan cara menggambar 
bekas daun yang dimakan pada kertas yang telas diketahui berat dan luasnya. Gambaran kertas yang merupakan luas daun yang dimakan ditimbang beratnya. Luas daun yang dimakan diketahui melalui konversi berat ke luas, dengan rumus sebagai berikut:

$$
\mathrm{LD}=(\mathrm{Wr} / \mathrm{Wt}) \times \mathrm{LK}
$$

dengan :

$\begin{array}{ll}\mathrm{LD} & =\text { luas daun yang dimakan } \\ \mathrm{Wr} & =\text { berat replika } \\ \mathrm{Wt} & =\text { berat total kertas } \\ \mathrm{LK} & =\text { luas total kertas }\end{array}$

Pengukuran Indeks Nutrisi. Metode yang digunakan dalam pengukuran indeks nutrisi mengacu pada metode gravimetri (Waldbauer, 1968). Pada awal pengujian disiapkan pakan buatan (diet) untuk larva S. litura, masing-masing pakan mengandung ekstrak daun sirsak dengan konsentrasi tertentu. Perlakuan ini menggunaan Rancangan Acak Lengkap dengan lima perlakuan konsentrasi ekstrak daun sirsak. Konsentrasi yang digunakan adalah $0 \% ; 0,63 \% ; 1,25 \% ; 2,5 \%$; dan 5,00\%. Setiap perlakuan terdiri dari lima ekor larva $S$. litura instar V yang baru ganti kulit dan belum makan. Larva tersebut ditempatkan secara individual dalam vial. Masing-masing perlakuan diulang tiga kali.

Perlakuan diawali dengan menimbang larva dan pakan untuk mengetahui berat basah awal, kemudian larva ditempatkan secara individual dalam vial, dengan pakan mengandung ekstrak dengan konsentrasi tertentu. Pengamatan dilakukan setiap 24 jam dan perlakuan diakhiri pada saat larva mencapai tahap instar V akhir. Selanjutnya larva, sisa pakan, dan feses dari masingmasing vial dikeringkan dalam oven bersuhu $60^{\circ} \mathrm{C}$ sampai mencapai berat kering yang konstan.

Respon kompensasi larva instar V S. litura terhadap adanya ekstrak daun sirsak dalam pakannya dihitung dengan metode gravimetri dari Waldbauer (1968), dengan rumus sebagai berikut:

1. Laju pertumbuhan relatif (Relative Growth Ratel RGR)

$$
\mathrm{RGR}=\mathrm{G} / \mathrm{TA} \text { (g/g berat badan / hari) }
$$

2. Laju konsumsi relatif (Relative Consumption Ratel $\mathrm{RCR})$

$$
\mathrm{RCR}=\mathrm{F} / \mathrm{TA} \text { (g/g berat badan / hari) }
$$

3. Efisiensi konversi makanan yang dicerna (Efficiency of Conversion of Digested food / ECD)

$$
\mathrm{ECD}=\mathrm{G} /(\mathrm{F}-\mathrm{f}) \times 100 \%
$$

4. Efisiensi konversi makanan yang dimakan (Efficiency of Conversion of Ingested food / ECI)

$$
\mathrm{ECI}=\mathrm{G} / \mathrm{F} \times 100 \%
$$

5. Perkiraan makanan yang dicerna (Approximate Digestibility/ AD)

$$
\mathrm{AD}=(\mathrm{F}-\mathrm{f}) / \mathrm{F} \times 100 \%
$$

dengan :

$\mathrm{G}=$ pertambahan berat larva selama periode makan, diperoleh dari pengurangan berat kering akhir larva dengan berat kering awal larva.

$\mathrm{F}=$ jumlah makanan yang dikonsumsi, diperoleh dari pengurangan berat kering awal pakan dengan berat kering akhir pakan.

$\mathrm{f}=$ berat kering feses.

$\mathrm{T}=$ lamanya waktu makan.

$\mathrm{A}=$ berat rata-rata larva selama perlakuan, diperoleh dari penambahan berat kering awal larva dengan berat kering akhir larva kemudian dibagi dua.

Pengamatan Struktur Membran Peritrofik. Konsentrasi yang digunakan adalah $0 \% ; 0,63 \% ; 1,25 \%$; $2,5 \%$; dan $5,00 \%$. Larva S. litura instar V dari masingmasing perlakuan diambil bagian midgutnya menggunaan pisau silet tajam. Midgut lalu difiksasi, didehidrasi, diinfiltrasi, selanjutnya ditanam dalam parafin sampai membeku.

Tahapan selanjutnya organ disayat melintang setebal 6 mikron menggunakan mikrotom putar. Pita sayatan kemudian ditempel secara seri pada kaca objek dengan perekat entelan untuk kemudian diwarnai dengan Hematoksilin-Eosin (HE).

Sediaan midgut kemudian diamati di bawah mikroskop. Penentuan persentase kerusakan dilakukan dengan cara pengamatan deskriptif, yaitu berdasarkan ada tidaknya kerusakan pada bagian membran peritrofik, sel epitel, dan haemosol akibat adanya ekstrak daun sirsak. Kerusakan bagian midgut dibedakan ke dalam 4 kategori yaitu :

- $\quad=0 \%$ (tidak ada kerusakan)

$+\quad=5 \%$ (kerusakan kecil)

$++\quad=10 \%$ (kerusakan sedang)

$+++\quad=15 \%$ (kerusakan besar) 
Analisis Data. Data yang diperoleh dari uji anti makan dianalisis menggunakan uji t, data pengukuran indeks nutrisi dianalisis dengan analisis ragam dilanjutkan dengan uji beda nyata terkecil dengan taraf nyata $1 \%$ dan 5\%, sedangkan data pengamatan struktur membran peritrofik dianalisis secara deskriptif dengan melihat tingkat kerusakan yang terjadi pada membran peritrofik.

\section{HASIL DAN PEMBAHASAN}

Uji Anti Makan. Pengujian aktivitas anti makan terhadap larva $S$. litura menunjukkan bahwa pada konsentrasi terendah $(0,63 \%)$ luas daun yang dimakan oleh larva uji adalah $0,90 \mathrm{~cm}^{2}$ dan secara statistik tidak berbeda nyata dibandingkan dengan luas daun yang dimakan pada pakan kontrol yaitu seluas $1,24 \mathrm{~cm}^{2}$. Pada konsentrasi $2,5 \%$ dan $10,00 \%$, luas daun yang dimakan oleh larva uji berturut-turut adalah $0,36 \mathrm{~cm}^{2}$ dan 0,13 $\mathrm{cm}^{2}$, secara statistik berbeda nyata dibandingkan luas daun yang dimakan pada pakan kontrol (Tabel 1).

Dilihat dari konsentrasi ekstrak yang diberikan terlihat bahwa semakin tinggi konsentrasi ekstrak maka luas daun yang dimakan semakin sedikit. Penurunan luas daun yang dimakan pada konsentrasi $0,63 \%$ sebesar 1,4 kali dibandingkan kontrol. Pada konsentrasi 2,50\% penurunan luas daun yang dimakan mencapai 3 kali lebih rendah dibandingkan kontrol, bahkan pada konsentrasi $10,00 \%$ luas daun yang dimakan mencapai 10 kali lebih rendah dibandingkan kontrol. Hambatan makan dari konsentrasi 0,63 sampai konsentrasi $10,00 \%$ berturutturut sebesar 28,9\%; 65,6\%; dan 90\% (Tabel 1).

Batasan mengenai konsentrasi yang efektif bagi senyawa yang bersifat anti makan belum ada standarnya. Beberapa peneliti mengatakan bahwa suatu senyawa yang mempunyai aktivitas sebagai anti makan terlihat berpengaruh pada konsentrasi yang dapat menghambat makan hingga 50\% (Bernays \& Chapman,
1978 dan Rose et al., 1981 dalam Schoonhoven, 1982). Namun beberapa peneliti lainnya mengatakan bahwa senyawa anti makan efektif bila dapat menghambat makan sekitar 80-100\% (Schoonhoven, 1982).

Pada konsentrasi 0,63\% luas daun yang dimakan oleh larva uji hanya sedikit lebih rendah dibandingkan kontrol, hal tersebut diduga karena konsentrasi ekstrak tersebut terlalu rendah, sehingga keberadaan ekstrak daun sirsak sebagai anti makan tidak dikenali oleh reseptor yang terdapat pada membran dendrite dari sensila yang mampu mengenali keberadaan senyawa anti makan. Menurut Hsiao (1985) reaksi serangga terhadap senyawa alelokimia tertentu tergantung pada dosisnya. Penghambatan total oleh suatu senyawa anti makan (feeding detterent atau antifeedant) terjadi pada kisaran dosis efektif tertentu.

Ekstrak daun sirsak mulai konsentrasi 2,50\% sudah menghambat makan larva $S$. litura melebihi 50\%, yaitu sebesar $65,60 \%$, sehingga dapat dikatakan bahwa ekstrak daun sirsak mulai konsentrasi 2,50\% mempunyai aktivitas anti makan. Ekstrak dengan konsentrasi 10\% pada penelitian merupakan konsentrasi yang mempunyai tingkat penghambatan makan paling tinggi yaitu $90 \%$.

Penurunan konsumsi makan larva uji diduga karena kandungan senyawa alelokimia yang terdapat dalam ekstrak daun sirsak. Kelompok senyawa pada tanaman sirsak adalah annonain, annoniin, muricine, muricinine, reticuline, serta asam hidrosianik (Morton, 1987). Menurut Schoonhoven (1982) alkaloid dan terpenoid sangat berpotensi sebagai penghambat makan pada sejumlah serangga. Biasanya pada larva Lepidoptera ditemukan suatu reseptor khusus berupa sel sensilla yang terdapat pada maksila. Sel tersebut dapat merespon berbagai alkaloid yang pada konsentrasi tertentu beraksi sebagai penghambat makan. Mulyaman et al. (2000) mengatakan bahwa senyawa yang

Tabel 1. Rata-rata luas daun $\left(\mathrm{cm}^{2}\right)$ yang makan oleh larva S. litura

\begin{tabular}{ccc}
\hline Konsentrasi $(\%)$ & Luas daun yang dimakan $\left(\mathrm{cm}^{2}\right)$ & Hambatan makan $(\%)$ \\
\hline 0 & $1,24 \pm 0,76 \mathrm{a}$ & 28,9 \\
0,63 & $0,90 \pm 0,40 \mathrm{a}$ & 65,6 \\
\hline 0 & $1,04 \pm 1,02 \mathrm{a}$ & \multirow{2}{*}{90,00} \\
\hline 0 & $0,36 \pm 0,23 \mathrm{~b}$ & \\
\hline 10,00 & $1,30 \pm 0,47 \mathrm{a}$ & \\
\hline
\end{tabular}

Semua nilai adalah rata-rata \pm SD. Data dianalisis dengan uji t dalam taraf nyata 1 dan 5\%. Angkayang diikuti huruf yang sama, menunjukkan tidak berbeda nyata $(\mathrm{P}>0,05)$. 
Tabel 2. Indeks nutrisi larva instar V S. litura yang terdedah pakan mengandung ekstrak daun sirsak

\begin{tabular}{|c|c|c|c|c|c|}
\hline $\begin{array}{c}\text { Konsentrasi } \\
(\%)\end{array}$ & $\begin{array}{c}\text { RCR (g/g berat } \\
\text { badan/hari) }\end{array}$ & $\begin{array}{c}\mathrm{RGR}(\mathrm{g} / \mathrm{g} \text { berat } \\
\text { badan/hari) }\end{array}$ & $\operatorname{ECD}(\%)$ & $\mathrm{ECI}(\%)$ & $\mathrm{AD}(\%)$ \\
\hline 0 & $0,32 \mathrm{a}$ & $2,42 \mathrm{a}$ & $34,07 \mathrm{a} \pm 3,70$ & $21,54 \mathrm{a} \pm 1,57$ & $41,15 \mathrm{a} \pm 2,41$ \\
\hline 0,63 & $0,22 b \pm 0,09$ & $2,37 \mathrm{ab} \pm 0,58$ & $30,46 a \pm 9,31$ & $17,87 \mathrm{~b} \pm 5,47$ & $=4,91$ \\
\hline 1,25 & $0,24 b \pm 0,06$ & $2,13 b c \pm 0,40$ & $32,58 \mathrm{a} \pm 8,74$ & $19,23 \mathrm{ab} \pm 4,12$ & $39,07 \mathrm{a} \pm 8,27$ \\
\hline 2,50 & $0,21 b c \pm 0,02$ & $2,05 \mathrm{c} \quad \pm 0,44$ & $32,41 \mathrm{a} \pm 7,62$ & $18,78 b \pm 20,43$ & $38,30 \mathrm{a} \pm 4,62$ \\
\hline 5,00 & $0,18 \mathrm{c} \pm 0,04$ & $2,06 \mathrm{bc} \pm 0,46$ & $29,70 \mathrm{a} \pm 6,98$ & $17,24 b \pm 3,01$ & $37,70 \mathrm{a} \pm 4,98$ \\
\hline
\end{tabular}

Semua nilai rata-rata \pm SD. Angka dalam satu kolom yang diikuti oleh huruf yang sama, menunjukkan nilai yang tidak berbeda nyata pada uji BNT $(\mathrm{P}<0,05)$.

berhasil diisolasi dari tanaman sirsak adalah acetogenin yang terdiri dari annonacin, asimisin, bulatacin, dan squamosin. Pada konsentrasi yang tinggi acetogenin akan bersifat anti makan pada serangga, sedangkan pada konsentrasi rendah bersifat sebagai racun perut dan dapat menyebabkan kematian.

Pengukuran Indeks Nutrisi dan Pengamatan Struktur Membran Peritrofik. Hasil pengujian menujukkan bahwa semua konsentrasi ekstrak daun sirsak yang diberikan mampu menurunkan laju konsumsi relatif (RCR) larva uji. Penurunan laju konsumsi relatif ini semakin besar dengan meningkatnya konsentrasi ekstrak yang diberikan (Tabel 2). Penurunan laju konsumsi relatif sudah terjadi pada perlakuan dengan konsentrasi terendah $(0,63 \%)$ dengan nilai laju konsumsi relatif sebesar $0,22 \mathrm{~g} / \mathrm{g}$ berat badan/hari. Namun penurunan laju konsumsi relatif pada perlakuan dengan konsentrasi $0,63 \%$ tidak berbeda nyata dengan perlakuan pada konsentrasi $1,25 \%$ maupun $2,5 \%$. Penurunan laju konsumsi relatif terendah terjadi pada pemberian perlakuan dengan konsentrasi 5,00\% sebesar $0,18 \mathrm{~g} / \mathrm{g}$ berat badan/hari, meskipun secara statistik nilai laju konsumsi relatif pada konsentrasi 5,00\% tidak menunjukkan perbedaan yang nyata dengan nilai laju pertumbuhan relatif pada perlakuan dengan konsentrasi $2,50 \%$. Persentase penurunan laju konsumsi relatif larva uji mulai konsentrasi $0,63 \%$ sampai $5,00 \%$ berturut-turut sebesar $31,79 \%$; 30,86\%; 36,11\%; dan 45,68\%.

Menurunnya laju konsumsi relatif larva uji diduga karena larva uji melakukan respon kompensasi akibat adanya senyawa alelokimia dalam pakan yang dikonsumsinya. Mulyaman et al. (2000) mengatakan bahwa senyawa yang berhasil diisolasi dari tanaman sirsak adalah acetogenin. Coloma et al. (2002) mengatakan bahwa acetogenin menghambat transfer elektron pada situs I, yaitu antara NADH dan ubiquinon dalam rantai transport elektron, sehingga pembentukan gradien proton terhambat dan cadangan energi pada gradien tersebut tidak dapat membentuk ATP. Tidak terbentuknya ATP mengakibatkan aktivitas larva uji menjadi terhambat.

Pemberian ekstrak daun sirsak mulai konsentrasi $1,25 \%$ sampai $5,00 \%$ dengan nilai laju pertumbuhan relatif (RGR) berturut-turut sebesar 2,13; 2,05; dan 2,06 $\mathrm{g} / \mathrm{g}$ berat badan/hari menunjukkan perbedaan yang nyata dibandingkan dengan kontrol. Nilai laju pertumbuhan relatif terendah $(2,05 \mathrm{~g} / \mathrm{g}$ berat badan/hari) terjadi pada pemberian ekstrak dengan konsentrasi 2,5\%. Persentase penurunan laju pertumbuhan relatif larva uji mulai konsentrasi $0,63 \%$ sampai $5,00 \%$ berturut-turut sebesar $1,78 \% ; 12,08 \% ; 15,31 \%$; dan $14,73 \%$. Penurunan laju konsumsi relatif berpengaruh terhadap penurunan laju pertumbuhan relatif. Menurunnya laju konsumsi relatif menyebabkan pemasukan makanan yang diubah menjadi biomassa menjadi lebih sedikit.. Banyak atau sedikitnya pakan yang dikonsumsi larva dipengaruhi oleh kualitas nutrisi dari pakan itu (Slansky \& Scriber, 1985).

Pemberian ekstrak daun sirsak menurunkan nilai efisiensi konversi pakan yang dimakan (ECI) dari larva uji, namun tidak berpengaruh terhadap nilai efisiensi konversi pakan yang dicerna (ECD) dan nilai perkiraan pakan yang dicerna (AD) larva uji. Penurunan nilai efisiensi konversi pakan yang dimakan (ECI) terendah $(17,24 \%)$ terjadi pada pemberian pakan yang mengandung ekstrak dengan konsentrasi 5,00\%. Penurunan nilai efisiensi konversi pakan yang dimakan diduga disebabkan oleh laju konsumsi relatif yang menurun, seiring dengan meningkatnya konsentrasi ekstrak daun sirsak yang diberikan. Hal tersebut menyebabkan laju pertumbuhan relatif dari larva uji juga menurun. Rendahnya jumlah pakan yang dikonsumsi mengakibatkan jumlah pakan yang diubah menjadi biomassa menjadi menurun, sehingga efisiensi konversi pakan yang dimakan menurun. Hal tersebut akan mempengaruhi bobot larva. Simpson \& Simpson (1990) mengungkapkan bahwa jika serangga tidak mungkin menyeleksi makanannya, karena tidak tersedianya 
Tabel3. Tingkat kerusakan struktur membran peritrofik larva instar $\mathrm{V}$ yang terdedah pakan mengandung ekstrak daun sirsak

\begin{tabular}{lccccc}
\hline \multirow{2}{*}{ Jaringan midgut } & \multicolumn{5}{c}{ Konsentrasi (\%) } \\
\cline { 2 - 6 } & 0 & 0,63 & 1,25 & 2,50 & 5,00 \\
\hline Membran peritrofik & - & - & - & - & - \\
Sel epitel & - & - & - & - & - \\
Haemosol & - & - & - & - & - \\
Tingkat kerusakan & $0 \%$ & $0 \%$ & $0 \%$ & $0 \%$ & $0 \%$ \\
\hline
\end{tabular}
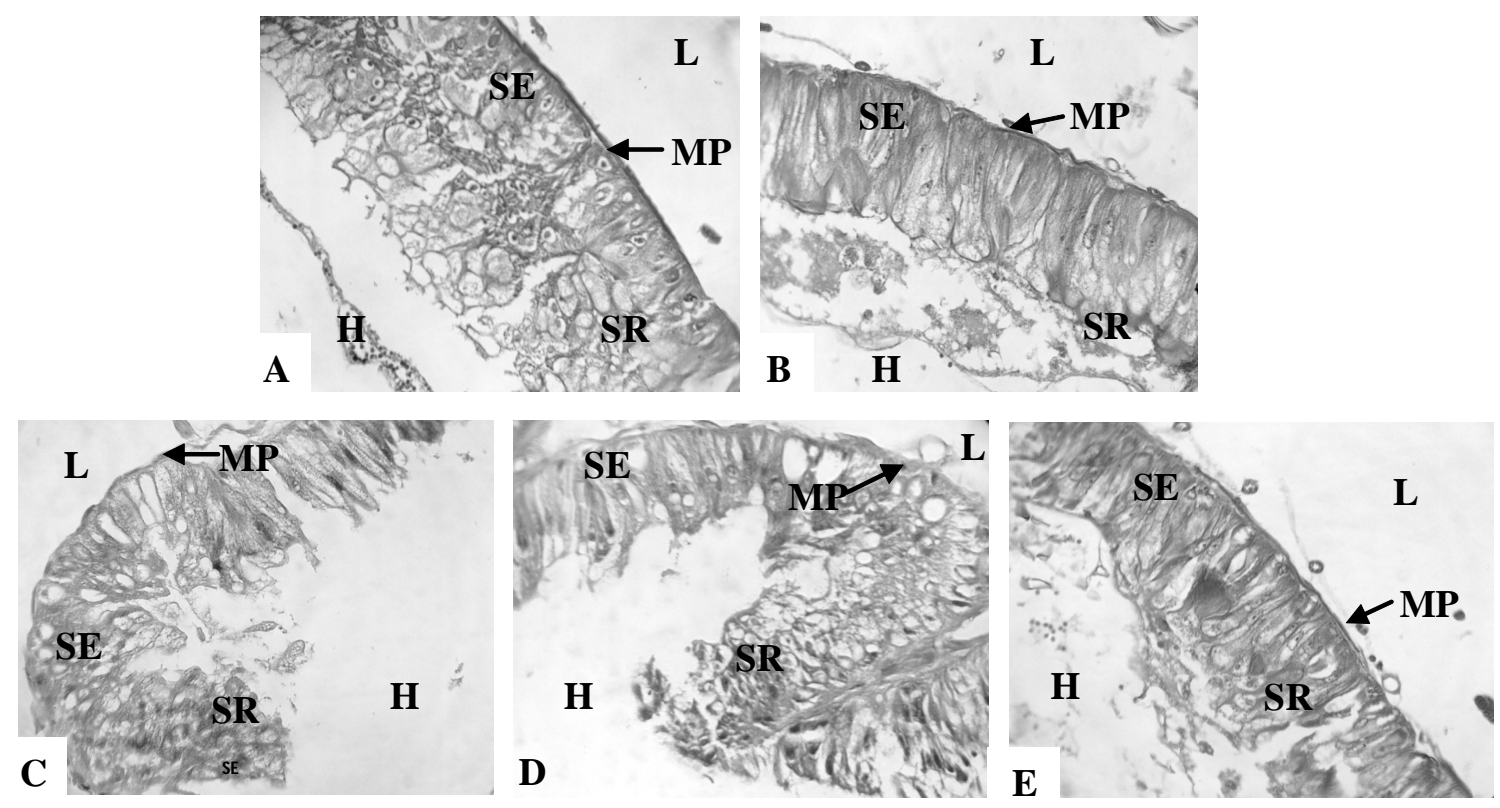

Gambar 2. Fotomikrograf penampang melintang midgut larva instar V Pewarnaan Harris Hematoxylin- Eosin.

Perbesaran 400 x. (A) Kontrol, (B) konsentrasi 0,625\%, (C) konsentrasi 1,25\%, (D) konsentrasi $2,5 \%,(\mathrm{E})$ konsentrasi $5 \% . \mathrm{MP}=$ membran peritrofik, $\mathrm{SE}=$ sel epitel, $\mathrm{L}=$ lumen midgut, $\mathrm{H}=$ haemosol, $\mathrm{SR}=$ sel regeneratif.

variasi makanan, maka konsekuensi yang muncul adalah kompensasi pada efisiensi konversi pakan yang dimakan.

Pemberian ekstrak daun sirsak tidak berpengaruh terhadap struktur membran peritrofik larva uji (Tabel 3 dan Gambar 1). Dari pengamatan struktur membran peritrofik larva uji, pada semua perlakuan ekstrak daun sirsak cenderung tidak dijumpai tanda-tanda kerusakan pada struktur membran peritrofik midgut larva instar V. Pada kelompok kontrol, membran peritorfik terlihat utuh, eksis dan tegas membatasi bagian permukaan selsel epitel midgut (Gambar 1A). Gambar 1B dan 1C terlihat struktur penyusun midgut kelompok konsentrasi 0,63 dan 1,25\% tidak mengalami kerusakan (cenderung utuh). Membran peritrofik di permukaan dinding midgut memperlihatkan sebagai suatu lapisan pelindung yang masih solid. Sel-sel epitel tersusun berdekatan rapat satu sama lain berbentuk kolumner tinggi (tiang/silindris), sedangkan kumpulan sel-sel regeneratif melekat di atas permukaan membran basal.

Gambar 1D dan 1E memperlihatkan struktur penyusun midgut yang diperlakukan dengan ekstrak konsentrasi 2,50 dan 5,00\% juga tidak mengalami kerusakan (cenderung utuh), meskipun terkesan menipis dibandingkan kontrol, serta dibandingkan dengan konsentrasi 0,63\% dan konsentrasi 2,50\%. Membran peritrofik di permukaan dinding midgut sebagai suatu lapisan pelindung yang masih protektif. Sel-sel epitel tersusun berdekatan rapat satu sama lain berbentuk kolumner tinggi (tiang/silindris) dengan gambaran inti ungu kebiruan tersusun di bagian basal epitel, sedangkan 
kumpulan sel-sel regeneratif melekat di atas permukaan membran basal.

Tidak adanya kerusakan pada struktur membran peritrofik larva uji diduga karena ekstrak daun sirsak tersebut lebih bersifat sebagai anti makan, sehingga tidak mempengaruhi struktur membran peritrofik larva uji.

\section{SIMPULAN}

Dari hasil penelitian ini dapat disimpulkan bahwa ekstrak daun sirsak mulai konsentrasi 2,5\% mempunyai aktivitas anti makan. Ekstrak daun sirsak menurunkan laju konsumsi relatif (RCR), laju pertumbuhan relatif (RGR), serta efisiensi konversi pakan yang dimakan (ECI) dari larva $S$. litura instar V, namun tidak mempengaruhi efisiensi konversi pakan yang dicerna (ECD) dan perkiraan pakan yang dicerna (AD). Penurunan laju konsumsi relatif, laju pertumbuhan relatif, dan efisiensi konversi pakan yang dimakan dari larva uji lebih disebabkan aktivitas anti makan dari ekstrak daun sirsak yang cukup kuat, sehingga tidak mempengaruhi struktur membran peritrofik larva $S$. litura instar V.

\section{SANWACANA}

Terimakasih kepada Direktorat Pembinaan Penelitian dan Pengabdian kepada Masyarakat Direktorat Jenderal Pendidikan Tinggi Departemen Pendidikan Nasional atas dana Hibah Bersaing XVII yang diberikan.

\section{DAFTAR PUSTAKA}

Coloma AG, Guadano A, Ines CD, Diaz RM, \& Cortes, D.2002. Selective action of acetogenin mitochondrial complex I inhibitors. CSIC, serrano115-dpdo, Madrid, Spain. http:// www.ncbi.nlm.nih.gov/pubmed/12562089. Diakses 9 November 2009.

Dadang, Fitriasari ED, \& Prijono, D. 2009. Effectiveness of two botanical insecticide formulation to two major cabbage insect pests on field application. J.ISSAAS. 15(1): 42-51.

Hsiao TH. 1985. Feeding behavior. Pp. 471-505. In: G.A. Kerkut and L.I. Gilbert, Eds. Comprehensive Insect Physiology Biochemistry and Pharmacology. Pergamon Press, Oxford.

Kardinan A. 2005. Pestisida Nabati: Kemampuan dan Aaplikasi. Penebar Swadaya, Jakarta.
Kalshoven LGE. 1981. The Pests of Crops in Indonesia. van der Laan PA (Rev. \& trans.) Rotschild GHL (Asssist.) PT Ichtiar Baru - van Hoeve, Jakarta.

Komansilan A, Abadi AL, Yanuwiadi B, \& Kaligis DA. 2012. Isolation and identification of biolarvacide from sousop (Annona muricata Linn) seed to mosquito (Aedes aegypti) larvae. International Journal of Engineeringi \& Technology IJET IJENS Vol. 12 no.03:28-32.

Lestari S. 2009. Tabel hidup Spodoptera litura Fabr. dengan pemberian pakan yang berbeda. Skripsi. Fakultas Biologi Universitas Jenderal Soedirman, Purwokerto.

Marwoto \& Suharsono. 2008. Strategi dan komponen teknologi pengendalian ulat grayak (Spodoptera litura) pada tanaman kedelai. Balai Penelitian Tanaman Kacang-kacangan dan Umbi-umbian, Malang.

Morton FJ. 1987. Soursop (Annona muricata) In: Fruit of warm climates. http://www.hort.purdue.edu / newcrop/nexus / Annona-muricata nex.html/ morton/soursop.html. Diakses 4 Februari 2008.

Mulyaman S, Cahyaniati, Adam I, \& Mustofa T. 2000. Pengenalan pestisida nabati tanaman hortikultura. Direktorat Perlindungan Tanaman, Departemen Pertanian, Jakarta.

Prijono D. 1999. Aktivitas insektisida ekstrak beberapa bagian tanaman Aglaica odorata Lour (Meliaceae) terhadap ulat crop kubis Crocidolomia binotalis. Kumpulan Intisari pada Forum Komunikasi Ilmiah Pemanfaatan Pestisida Nabati. Balai Penelitian Tanaman Rempah dan Obat. Pusat Penelitian dan Pengembangan Tanaman Perkebunan, Departemen Kehutanan dan Perkebunan, Bogor.

Schoonhoven LM. 1982. Biological aspects of antifeedant. Ent. Exp. \& Appl. 31: 57-69.

Simanjuntak F, Maimunah, Noer Z, Zahara H. 2007. Pemanfaatan daun sirsak dan berbagai jenis umpan untuk mengendalikan hama rayap di laboratorium. www. bbkp Belawan. deptan.go.id./kary\%.20Tulis? Sirsak.pdf. Diakses 3 Oktober 2009.

Simpson SJ \& Simpson CL. 1990. The mechanism of nutritional compensation by phytophagus insect. 
Pp. 111-160. In: Insect-plant interaction. Vol.2. CRC press, Florida.

Slansky F Jr. \& Scriber JM. 1985. Food consumption and utilization Pp. 88-122. In: Kerkut G.A \& Gilbert L.I., Eds. Comprehensive insect physiology, biochemestry, and pharmacology. Vol.4. Pergamon press. Oxford.

Tjokronegoro RK. 1987. Penelusuran senyawa kandungan Tumbuhan Indonesia: Bioaktif terhadap serangga. Disertasi. Universitas Padjadjaran, Bandung.
Waldbauer GP. 1968. The Consumption and Utilization of Food by Insect. Pp. 229-288. In: Beament JWL, Treherne JE \& Wigglesworth VB, Ed. Advances Insect Physiology. Academic Press, London.

Yus Y. 1996. Pengaruh ekstrak biji Annona muricata L. terhadap indeks nutrisi, kelulushidupan, pertumbuhan, dan perkembangan larva Heliothis (Helicoverpa) armigera Hubner. Tesis Magister Sains (Tidak dipublikasikan). ITB. 